\title{
Assessing the Impact of Different Land Use Activities on the Vegetation Cover and Sustainable Livelihoods along the Banks of Niles at Khartoum State, Sudan
}

\author{
Galal E. Omer ${ }^{1,2 *}$, Babiker A. Elhassan ${ }^{3}$, Fatima A. Mohammed ${ }^{2}$ \\ ${ }^{1}$ Department of Forest Protection and Conservation, Faculty of Forestry, Shambat Campus, University of \\ Khartoum, Khartoum North, Sudan \\ ${ }^{2}$ School of Agricultural, Earth and Environmental Sciences, Pietermaritzburg Campus, University of \\ KwaZulu-Natal, Pietermaritzburg, South Africa \\ ${ }^{3}$ Academician and Consultant in Natural Resource Management, Khartoum, Sudan \\ Email: "gekhaled189@gmail.com
}

Received 30 April 2015; accepted 17 May 2015; published 20 May 2015

Copyright (C) 2015 by authors and Scientific Research Publishing Inc.

This work is licensed under the Creative Commons Attribution International License (CC BY).

http://creativecommons.org/licenses/by/4.0/

(c) (i) Open Access

\begin{abstract}
Land use activities (LUA) have a significant impact on the level and situation of vegetation characteristics and in turn affect human population as they are considered as the main global environmental changes. This study analyzed land use patterns in three different locations in Khartoum, Sudan: banks of River Nile, Blue and White Nile. The main objective of the present study were 1) to assess the changes in land use and their impact on vegetation cover and sustainable livelihoods of the population, and 2) to identify the factors behind land use changes along the Banks of Niles, Khartoum State. The study data used were field survey (questionnaire) which revealed the existence of five types of land use patterns: roads, human settlements, agricultural and plantations farms, and industrial of brick-kilns making and investment areas. The primary data were collected through social survey (questionnaire) as face-to-face interviews with local communities in the study area and by observations. The secondary records during the field survey were collected from the Ministry of Agriculture and Forestry, and the Forest National Corporation (FNC) documents, scientific papers and annual reports. SPSS was used to analyze the data acquired from questionnaires. Results showed that agricultural land, and industrial and residential areas increased while forests and bare lands decreased as a result of changes imposed by the government and local population with consequent land degradation in terms of environmental value and productivity. Interestingly, it was found that the impact of land use on vegetation cover and livelihood of the popu-
\end{abstract}

${ }^{*}$ Corresponding author.

How to cite this paper: Omer, G.E., Elhassan, B.A. and Mohammed, F.A. (2015) Assessing the Impact of Different Land Use Activities on the Vegetation Cover and Sustainable Livelihoods along the Banks of Niles at Khartoum State, Sudan. Journal of Geoscience and Environment Protection, 3, 52-61. http://dx.doi.org/10.4236/gep.2015.33005 
lation was very complex and dynamic and that the main influencing factors in this process were climate fluctuations and human illegal interference. For instance, vast areas in west bank of White Nile were changed from agriculture to residence and investment. In conclusion, land use requires a clear plan for optimum utilization. Various human activities are behind these changes, which have led to deterioration of forest cover and loss of the source of income of local population. Because of such alarming changes, decision makers should initiate efficient plans and management of forests to minimize changes in land cover, especially in arid and semi-arid areas. We recommend that a sound land use plan should be revised often to ensure rehabilitation, reduce vulnerability to desertification and halt the encroachment by construction of facilities and buildings at the expense of environmental issues.

\section{Keywords}

\section{Land Use Activates, Sustainable Livelihoods, Sunut Natural Forest Reserve, Sudan}

\section{Introduction}

An important issue in globe worldwide, sustainable livelihoods, vegetation and forest status study is the understanding and knowledge about the impact of land use activities/changes on the human life around the forests. This is to determine the main factor affecting the sustainable livelihoods such as land use and forest activities [1]. Land use activities (LUA) and forest activities have a significant impact on population living and are therefore considered to be two main global environmental changes which have major impacts on economic, social, and ecological aspects [2] [3]. LUA are fundamental variables that influence and link with many parts of the human and physical systems, as they are vital data components for many aspects of environmental change [4] [5]. The environmental changes and disturbance of forest ecosystems are widely caused by the humans living in and around the forests and different LUA [6] [7]. The environment and LUA have significant effects on the basic ecosystem processes including biogeochemical cycling and erosion of soils and human susceptibility [8]-[11].

Moreover, LUA also have affected human living directly and indirectly through affecting forest ecosystems; habitat destruction has negative effects within the remaining forest environment [12]. Forest ecosystems affected by LUA in turn lead to destruction of natural habitats through different human activities, the growing pressures, intensive land use interventions due to a growing human population and the subsequent growing demand for food and energy around the forests which are considered to be a huge factor affecting forests in developing countries and Sahelian environments such as Sudan [4] [13]-[16]. Sudan is the largest country in Africa, with an area of approximately 2.5 million square kilometers. Sudan is characterized by diverse climatic conditions from desert (0 - $100 \mathrm{~mm}$ rainfall per annum) to savanna (200 - $850 \mathrm{~mm}$ rain fall per annum) [16]. This diversity results in different ecological regions from the desert in the north to the high rainfall woodland savanna in the south [16]. It is rich in its natural resources; among them are the forest resources, which are either reserved, or non-reserved. Natural resources play a vital role in the economy, social and welfare of the people [1]. In Sudan, the population demand for food and energy from different forest and agricultural products, mainly fuel wood and charcoal, had increased during the period 1993-2003, as these were extensively used as major sources of energy for more than $80 \%$ of the population in the country [4]. Fuel wood and charcoal production is still one of the major factors causing reduction in Sudan natural forest area and affecting the sustainable livelihoods of the population; increased human population has also aggravated the land use change problems [16].

In addition, the demand for agricultural land systems and increased activities of land use patterns have put high pressure on forests which has led to altered vegetation cover, changes to the composition and structure of forest vegetation of adjacent forest ecosystems as well as negatively impacting on most African forests ecosystems and human living over the past decades [4] [8] [17]-[19], particularly in Sudan [1] [20]. Therefore, forest resources provide a wide range of benefits including wood for energy, pole and sawn timber beside non-wood forest products. However, the forest resources were subjected to severe degradation over the past decades. The forest cover in Sudan is also estimated to be $12 \%$ of the total area of the country while it was $18 \%$ in the early $1980 \mathrm{~s}$ and $36 \%$ in 1958 . This has declined to $25.6 \%$ in 2000 , which shows the fast deterioration of this resource [3] [4]. 
Generally, forest cover and resources were decreased by several factors such as drought, uncontrolled activities of desertification through land clearing for mechanized agriculture, population pressure, overgrazing, bush burning, traditional and shifting cultivation due to lack of sound management and optimized land use plans [1] [3] [4] [16]. Sound forest management should be integrated into the land use plans of other forest resources, as different LUA affect the conservation and management of such forest resources [1] [21]. The development of an integrated forest management plan requires combining information from the forests and land-use records [21]. The current land use categories between latitude $10^{\circ} \mathrm{N}$ and $16^{\circ} \mathrm{N}$ in Sudan represent the semi-arid and savanna zones that contain the major agriculture, rangelands and forest lands [22].

In Khartoum State zone, large areas of the forest, traditional agricultural systems and rangeland were put under modern mechanized farming, and civil constructions. These activities made the forests unable to meet the population's source of income requirements. Over-cutting of wood to satisfy the local people's needs for charcoal and fire wood to improve their economic income has contributed to natural forest deterioration [1] [20]. The total SNFR area is reduced due to over-cutting, buildings, and investments as a result of increasing human population, and the increase in demand for food and energy. These are the main challenges to the conservation and rehabilitation of the SNFR. Eltayeb [20] states that the great horizontal expansion of Khartoum State since 1993 has been quite remarkable and the three towns have grown differentially, with Khartoum constituting $43 \%$ of the total area of Khartoum State. Major reasons for this expansion include the high rate of population growth, abundance of flat land, availability of cheap building material (clay), and the government housing policy [20] [23]. These reasons had a negative impact on the SNFR cover and population livelihood expansion in building and infrastructure and lead to reduce the source of income. Therefore, the objectives of the present study are 1) to assess the changes in land use and their impacts on the vegetation SNFR cover and sustainable livelihoods of the population, and 2) to identify the factors behind land use changes along the Banks of Niles, Khartoum State. In order to achieve the objectives, the following hypotheses need to be empirically established: the forest resources and the changes in LUA have been depleted as a result of mismanagement and the changes in LUA and practices are contributing potentially to changes in the area of SNFR.

\section{Materials and Methods}

\subsection{Study Area}

The study was conducted along parts of the Banks of the three Banks of Niles at Khartoum State, Sudan (Figure 1). It is located between latitudes $15^{\circ} 26^{\prime} \mathrm{N}$ and $15^{\circ} 45^{\prime} \mathrm{N}$, and longitudes $32^{\circ} 25^{\prime} \mathrm{E}$ and $32^{\circ} 40^{\prime} \mathrm{E}$ at an altitude of $405.6 \mathrm{~m}$ above sea level [23]. It almost lies in the center of Sudan at the junction of the Blue and White Nile and occupies an area of about $2611 \mathrm{sq}$. km. It is the smallest state in the Sudan, extending from the margins of the desert in its northern extremity to semi-wet humid regions southwards. The White Nile and Blue Nile unite at Khartoum and from the main Nile (River Nile), which flows northward and divides the country area into two parts, one to the west and the other to the east [1] [23]-[25]. The terrain is generally flat or gently sloping, only interrupted by occasional hills of rocky outcrops while sand dunes provide a gently undulating topography [23]. Khartoum State is the capital of Sudan and is located on the edge of the River Nile system from upstream to downstream. The State was selected for this study not only because it is the capital of Sudan, but also because it is located in the point of meeting for the main two Rivers Blue and White Niles. Therefore, the study area focuses on area along the Banks of Niles at Khartoum State and thus is appropriate to meet the objectives of this study. Moreover, it is heavily populated and has active development activities. Khartoum is located at the confluence of the White and Blue Niles at 370 meters above sea level [26].

\subsection{Field Data Collection}

The field campaign was carried out on 5th July 2008. The first field visit was carried out along the Banks of Niles and SNFR at Khartoum State, Sudan, to update information on the area and delineate boundaries for area remapping, using GPS (Global Positioning System). Materials and methods included the description of the scope of the study, the target group, and sample selection. Moreover, the data collection instrument (questionnaire) is described with regard to its construction, validity and field testing as well as the procedures and methods employed for data analysis. The study was undertaken for the purpose of assessing the impact of land use changes on vegetation cover and population sustainable livelihoods along parts of the waterfronts of a 


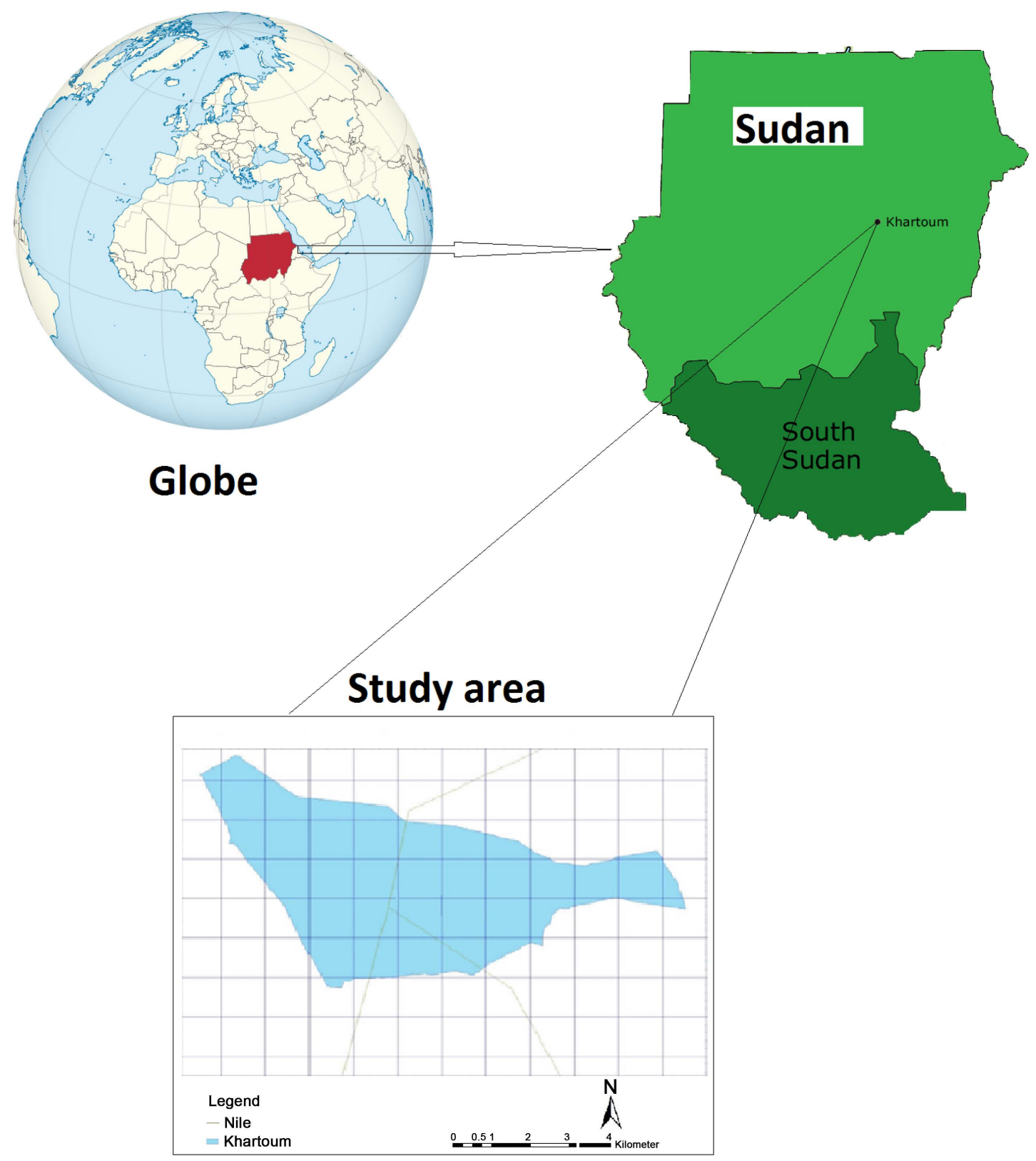

Figure 1. Location of study area in Khartoum State of Sudan.

designated area in Khartoum State. In this study, two types of data were used to collect the necessary information to achieve the research objectives, namely: primary and secondary information. The primary data was collected through household survey (questionnaire) with the purpose of investigating the perception of the people on land and resource status. Direct observations were recorded during the terrestrial survey and the existing LUA of natural resources were identified. The source of the secondary data included FNC documents, projects documents, Ministry of Agriculture and Forests, Civil engineering records, relevant previous studies, scientific papers and annual reports.

\subsection{Sampling Procedure and Techniques (Selection of Locations and Households)}

The sampling procedure and technique used in this study is simple random sampling for selection of locations and households. Selection of location was based on availability of LUA in the study area. Three sites were se- 
lected to represent the study area, namely, main Nile, Blue and White Niles. Taking Khartoum city as the focal point, about five kilometers along each of the Niles was delineated as the three main sampling sites. The reconnaissance survey was conducted to cover both banks of each Nile along the specified $5 \mathrm{~km}$. LUA were recorded by type, extent and current conditions. A reconnaissance survey was also conducted along narrow strips of 0.5 $1.0 \mathrm{~km}$ at both banks of each of the three Niles. Parameters to be measured or observed and recorded included information related to various land use patterns including farming, brick making, investment and illegal buildings, forests (tree and shrubs) and bare areas and to identify vegetation cover. Random samples from each LUA were taken and 40 farmers were randomly selected to represent the various patterns. A total of 34 random samples represented brick making, 30 samples were taken for buildings, and SNRF was selected to represent forests type and 12 random samples to represent bare area. The sample size was adjusted according to the overall number of the different LUA.

\subsection{Social Economic Survey}

The three sites do not constitute a proper dwelling for the target group and consequently it is difficult to identify proper households. Moreover, the reconnaissance survey was carried out to collect some basic data that will help in preparing the questionnaire as well as in delineating the boundaries of the study sites. The construction of the questionnaire was made according to the standards set for proper formulation of appropriate questions. The supervisor and other experts helped in construction of the final format. The following guidelines of Burchinal [2] were also given special consideration in the construction of the questionnaire. People living or just working on the sites are considered as the target group. Residence and mode of production and consumption are considered as the main criteria for defining households. These criteria are diffused in the study area, hence, people working and encountered on the site were interviewed. The filling of questionnaires was carried out for people available in the study area, and a total number encountered of 116 respondents were selected for this study along the Banks of Niles. Generally, observations were made on the types and status of vegetation, forest cover, and trend land use and land use types along the designated waterfronts. Accessible areas of the forest tract between the three locations of Khartoum State were visited and the status of the vegetation cover in each site was captured by the use of Digital Camera. This was intended to provide pictorial evidence of the degraded parts of the forest and to register the several of LUA.

\section{Statistical Analysis}

The statistical analysis was carried out through exploratory manipulation of the data obtained from the study area. This process was accomplished by critically examining the data through the use of simple techniques of analysis. The Statistical Package for the Social Sciences (SPSS) software was used for social survey data. The main tools are the construction of simple tables and selected cross tabulation which allows tentative answers to many of the questions being asked in the social survey.

\section{Results and Discussion}

The general characteristics of respondents are of great importance for showing the salient features of the social aspects of the study area and for using the information in the analysis and assessment. These characteristics include education level, occupation, sex, source of income and the current status of the land cover and their direct or indirect influence on land use, population livelihoods and the overall environment.

\subsection{The Economic Activities in the Study Area}

Table 1 shows the five main dominant economic activities and source of income of the respondents in the study area namely: agricultural systems (farming), grazing, trading, private business and other. About $47.8 \%$ of the respondents rely on private business, $31.1 \%$ rely on farming, $6.8 \%$ of them are engaged in trading, while $5.6 \%$ rely on Government employer, and $8.5 \%$ of them mentioned that the local populations have been partially involved in participation in afforestation process, grazing and NGOs (Table 1). Generally, the main dominant activities are private business and agricultural systems for sustainable livelihood because the local people rely on different agricultural systems and some of them are employed in Government jobs beside their private business (Table 1). 
Table 1. Economic activities and source of income according to respondents.

\begin{tabular}{|c|c|c|c|c|c|}
\hline \multirow[t]{2}{*}{ Age group } & \multicolumn{5}{|c|}{ Source of income } \\
\hline & Private business & Trading & Farming & Employer & Other \\
\hline$<25$ & 40.0 & 20.0 & 40.0 & 0.0 & 0.0 \\
\hline $25-34$ & 46.7 & 0.0 & 20.0 & 13.3 & 20.0 \\
\hline $35-44$ & 64.3 & 7.1 & 14.3 & 7.1 & 7.1 \\
\hline$>45$ & 40.0 & 0.0 & 50.0 & 3.0 & 7.0 \\
\hline Average & $47.8 \%$ & $6.8 \%$ & $31.1 \%$ & $5.6 \%$ & $8.5 \%$ \\
\hline
\end{tabular}

\subsection{Impact of Land Use Changes on Vegetation Cover and Population}

The land use changes affecting people lives are: vegetation, forest cover, and causes of land degradation according to the respondents as shown in (Figure 2). Most of respondents (46.3\%) asserted that change in land use has led to deterioration in vegetation cover as a consequence of illegal felling, overgrazing and conversion of forest land to other uses, $29.2 \%$ of the respondents mentioned that the changes led to replacement of activities and migration of local people to other land uses, $9.6 \%$ of the respondents mentioned environmental pollution which has been caused by the bricks kilns, the relative industrial expansion, $8.7 \%$ of them believed that the change in land use practice is behind the conflicts while $6.2 \%$ of the respondents believe that this change has resulted in reduction in production (Figure 2).

\subsection{The Factors of Deterioration and the Current Status of Vegetation Cover}

The factors responsible for the deterioration of forest and tree cover in the study area, according to the respondents, are shown in Table 2. The status of the forest was described into two factors: deteriorated and constant/ improving. $86.4 \%$ of the respondents asserted that the current status of the forest is degraded, while $13.7 \%$ described the status as constant or improving (Table 2). Different human activities and interferences such as overcutting, overgrazing, expansion in agriculture and buildings were mentioned by $65.28 \%$ of the respondents as the main factor behind the deterioration of the vegetation and tree cover, while natural factors were mentioned by $23.18 \%$. Respondents were able to nominate different reasons responsible for the change land use and these reasons affect forest cover and people's life in the study area. Most of respondents believe that the land use change is due to Government's use of its lands for settlement and investments buildings and that these changes affect vegetation cover and population livelihoods, as the population has increased in the last years, while some of them believe these changes are because of local people illegally cutting trees thereby converting forest lands to other uses. This result is consistent with Ghenaim [6]. Khaleel [5] has mentioned the human and natural factors for changes in land use and reported that these factors have great negative impacts in the vegetation cover in some locations of Sudan. While the constant or improving factor was mentioned by only $7.45 \%$ of the respondents who attributed this to the effect of awareness and legislation, $4.0 \%$ of the respondents reported that this is due to the fact that reliance on forest was weak and that this includes the degree of dependence on the vulnerable forest, grazing is not a forest activity, environmental awareness, extension, continued administration and regulation cutting rotation (Table 2).

In general, previous studies have shown that at present natural and forest resources in Sudan are evaluated to have deteriorated to approximately 0.8 billion $\mathrm{m}^{3}$ standing crop while it was 2.4 billion $\mathrm{m}^{3}$ in the mid-seventies. Since the time when reservation of natural forests started in 1932, the policy was to concentrate on the management of forests reserves under government control, to organize felling program, protection, conservation, development and management. The authors have concluded that the main cause of desertification is human activities through over-exploitation of lands through over-cultivation, over-cutting of wood and overgrazing [1] [5]-[7] [11]. All these are conflicting and sometimes antagonistic land use patterns.

\subsection{Trends of Land Use in the Study Area}

Table 3 shows the different types of new land use trends in the study area. The dominant types of land use 


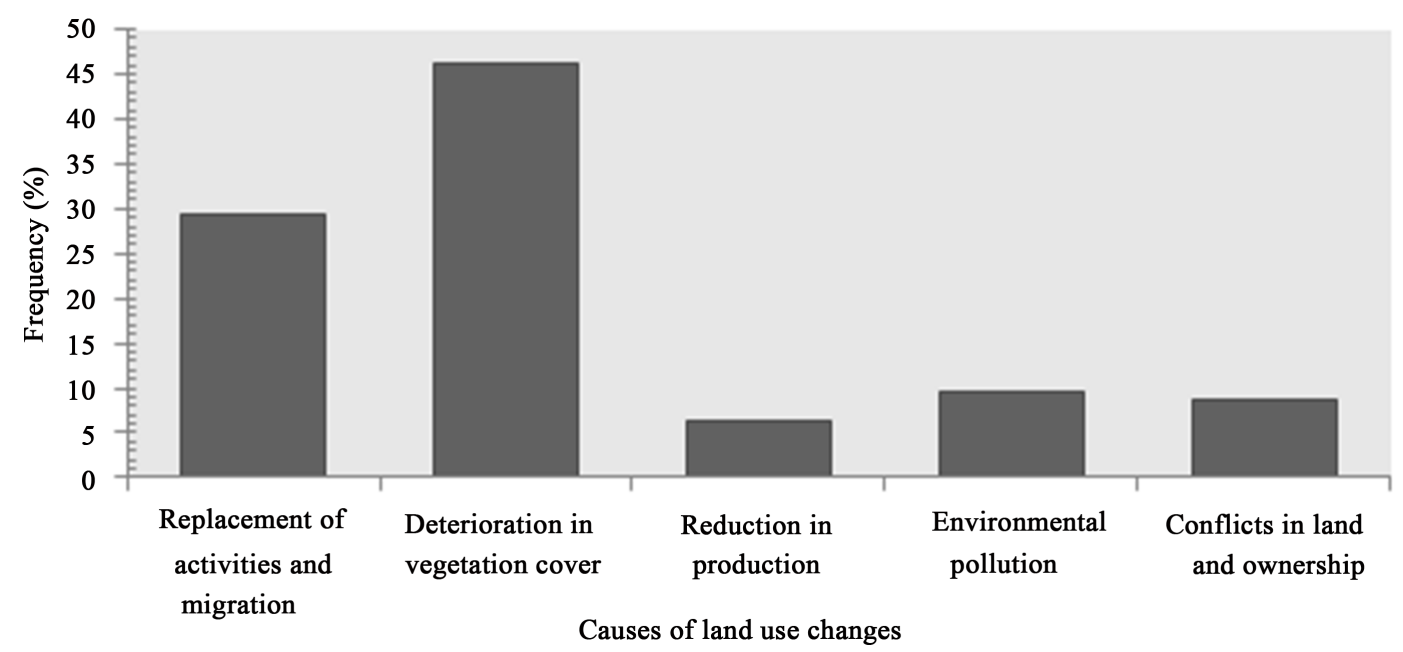

Figure 2. Consequences and causes of land use changes in the study area.

Table 2. Current status of vegetation cover and the deterioration factors.

\begin{tabular}{|c|c|c|c|c|c|c|}
\hline \multirow{2}{*}{ Age group } & \multicolumn{2}{|c|}{ Forest current status } & \multicolumn{2}{|c|}{ Causes for degradation } & \multicolumn{2}{|c|}{ Causes for constant or improving } \\
\hline & Degraded & Improving & Human factors & Natural factors & A awareness \& legislation & Reliance on forest \\
\hline$<25$ & 60.0 & 40.0 & 60.0 & 20.0 & 13.0 & 7.0 \\
\hline $25-34$ & 93.3 & 6.7 & 67.6 & 21.4 & 6.7 & 4.0 \\
\hline $35-44$ & 78.6 & 21.4 & 63.5 & 21.3 & 10.1 & 5.0 \\
\hline$>45$ & 100 & 0.00 & 70.0 & 30.0 & 0.00 & 0.0 \\
\hline Average & $86.4 \%$ & $13.7 \%$ & $65.28 \%$ & $23.18 \%$ & $7.45 \%$ & $4.0 \%$ \\
\hline
\end{tabular}

Table 3. Trends of land use and factors behind the new trends in the study area.

\begin{tabular}{ccccccc}
\hline \multirow{2}{*}{ Age group } & \multicolumn{2}{c}{ New land use trends } & \multicolumn{3}{c}{ Factors behind new trends } \\
\cline { 2 - 7 } & $\begin{array}{c}\text { Agriculture } \\
\text { expansion }\end{array}$ & $\begin{array}{c}\text { Buildings } \\
\text { expansion }\end{array}$ & $\begin{array}{c}\text { Industrial } \\
\text { expansion }\end{array}$ & $\begin{array}{c}\text { Local } \\
\text { people }\end{array}$ & $\begin{array}{c}\text { Government } \\
\text { activities }\end{array}$ & $\begin{array}{c}\text { Natural } \\
\text { factors }\end{array}$ \\
\hline$<25$ & 40 & 60 & 12 & 23 & 60 & 5 \\
$25-34$ & 40 & 60 & 15 & 26 & 50 & 9 \\
$35-44$ & 35 & 65 & 20 & 18 & 48 & 14 \\
$>45$ & 70 & 30 & 9 & 62 & 18 & 11 \\
Average & $46.25 \%$ & $53.75 \%$ & $14.00 \%$ & $21.25 \%$ & $55.00 \%$ & $9.75 \%$ \\
\hline
\end{tabular}

change included agricultural expansion and buildings expansion. Respondents mentioned different reasons responsible for the change in land use and the effect of the change on forest cover and people's lives. The natural condition, the government, local people and industrial expansion were the main factors behind the new land use trends. The previous land use converted to expansion in buildings and agriculture of $46.3 \%$ and $53.8 \%$, respectively according to respondents mentioned in Table 3 . The present study defined four factors behind the new trends of land use namely: $55.0 \%$ of the respondents believed that the land use change is due to the fact that the government is assigning the land for investment buildings. This change is affecting vegetation cover and population livelihoods, especially after the increase in the population. $21.25 \%$ of the respondents asserted that these changes are attributed to the fact that people practice illegal felling and convert forest and bare lands to other uses such as investment and housing buildings, while $14.0 \%$ of respondents mentioned that the change is due to industrial expansion and $9.8 \%$ of them attributed it to natural condition in the study area (Figure 3). 


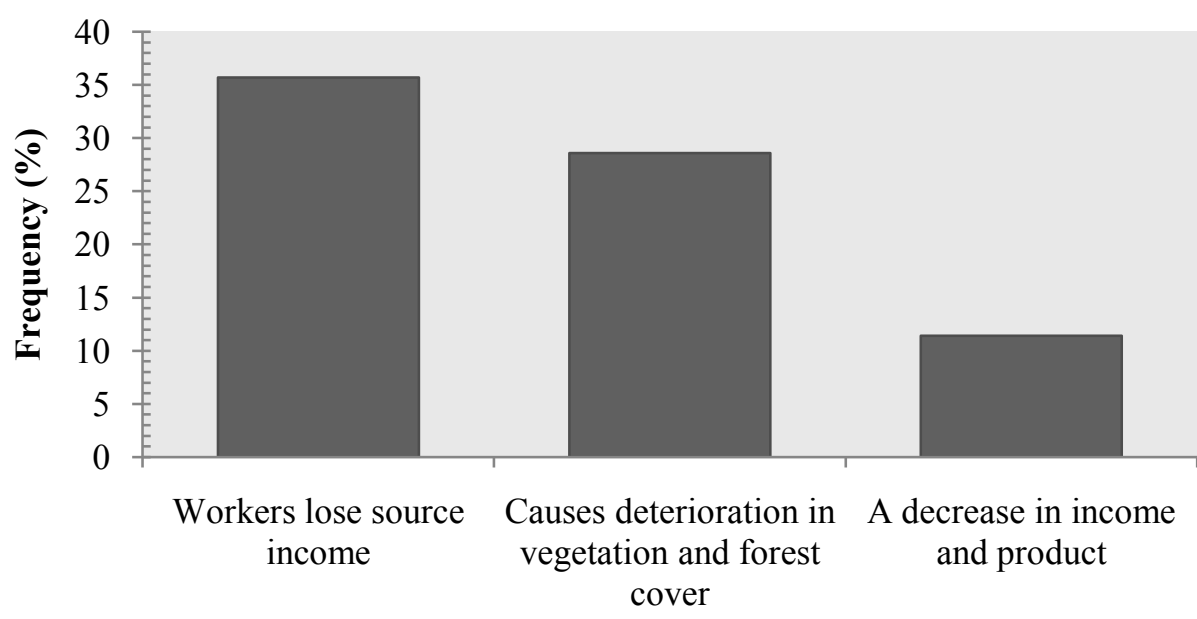

Factors affecting on population

Figure 3. Expansion in buildings factors affecting land use change.

In addition, expansions in buildings factors affecting land use change were shown in (Figure 3). Respondents were able to mention different factors responsible for the change in land use practice in the study area. They attributed this change to low levels of awareness and weak extension services. Figure 3 shows that $35.7 \%$ of the respondents asserted that low or lack of awareness and extension services are behind the land use changes and lead to loss of income for the labourers, $28.6 \%$ of the respondents mentioned that the changes in land use led to deterioration of vegetation cover that have indirectly affected the local community and reduction of production and income also stems from the changes (Figure 3).

\subsection{Negative Impact of Human Settlement}

Respondents were able to identify different negative aspects of population activities responsible for the change in land use in the study area. The respondents who believe that the changes of land use have increased or remained stable attributed their perception to awareness of the local people with regard to the ideal land use practices. $75.4 \%$ of respondents in Table 4 attribute the changes in land use to urbanization. Table 4 also shows the different types of urbanization, where $82.0 \%$ of the respondents from age group more than 45 mentioned that housing plans are the one of the reason of changes in land use and $75.0 \%$ of the respondents from age group less than 25 mentioned that housing plans are the main reason for the change, $20.6 \%$ of the respondents mentioned that investment building is the one of causes behind the change, while $14.3 \%$ of them asserted that the illegal buildings are behind change of land use and deterioration of vegetation cover for all the age groups of respondents.

\section{Conclusions}

The aim of this study is to assess changes in land use and its impacts on the vegetation cover and sustainable livelihoods of the population along a section of the waterfronts in Khartoum State. The present study shows that the impacts of changes on population life include reduction of production, replacement and migration, reduction of income and some socio-economic problems. The study also reveals that various human activities are behind this change and that these changes have led to the deterioration of forest cover, consequently resulting in the loss of source of income for the local population. Different factors are responsible for the deterioration of the vegetation cover in the study area. The main factors are illegal felling and overgrazing due to expansion in agriculture and buildings. Deterioration is also due to over-cultivation by traditional or mechanized farming, population increase, climate change and fires. Some locations in the study area were converted into buildings, kilns and residential areas at the expense of forests and pastures.

Our study provided land use change information that could be used as essential information for decisionmaking regarding land management and policy-making strategies in a natural resource area like SNFR. The study concluded that the changes in land use had affected both forest cover and people's lives and that the use of 
Table 4. Negative impact of human settlement.

\begin{tabular}{ccccc}
\hline & & \multicolumn{3}{c}{ Types of urbanization } \\
\cline { 3 - 5 } Age group & Urbanization & Investment buildings & Housing plans & Illegal buildings \\
\cline { 3 - 5 } & 100.0 & 10.0 & 75.0 & 15.0 \\
25 & -34 & 26.7 & 60.0 & 13.3 \\
$35-44$ & 71.4 & 35.7 & 45.3 & 19.0 \\
$>45$ & 70.0 & 8.0 & 82.0 & 10.0 \\
Average & $75.4 \%$ & $20.60 \%$ & $65.60 \%$ & $14.3 \%$ \\
\hline
\end{tabular}

land required a clear plan to optimize the use process. The natural conditions, the government, local people and industrial were the main factors behind the appearance of the new land use trends. The study suggested some recommendations which were expected to contribute to designing of appropriate and ideal land use patterns which, in turn, were expected to improve people's sustainable livelihoods, reduce desertification and increase income of the population of the study area. Development, restoration and re-vegetation of degraded lands along the two banks (Blue and White Niles of Khartoum State) are highly recommended because these parts are subjected to intensive and unplanned agricultural activities.

\section{Acknowledgements}

We would like to thank the University of Khartoum, Sudan and DAAD (Deutscher Akademischer Austausch Dienst) e.V. German Academic Exchange Service for funding the research. Our gratitude further extends to Dr. Elamin Sanjak and Dr. Omer Musa for their helpful comments and assistance during data analysis.

\section{References}

[1] Omer, G.E. (2009) Impact of Land Use Changes on Vegetation Cover and Sustainable Livelihoods along the Banks of Niles at Khartoum State. Ph.D. Dissertation, Department of Forest Protection and Conservation, University of Khartoum, Khartoum, 101.

[2] Burchinal, L.S. (1989) Lecture Notes and Steps in Conducting a Survey. Presented at the 2nd Annual Forestry Extension Workshop on the Methodologies and Techniques in Conductive Forestry Extension Program in Sudan.

[3] FAO (1997) State of the World's Forest. Situation and Prospects for Forest Conservation and Development, Rome.

[4] FNC (2003) Progress and Issues Related to Implementation of IPF/IFF Proposals for Action. National Report to the Fifth Session of the United Nations Forum on Forests, Khartoum.

[5] Khaleel, A.M. (2000) Land Use in Jebal Awlia in Sudan. M.Sc. Thesis, Nelain University, Department of Geography, Khartoum, 67.

[6] Ghenaim, Z.A. (1971) Study on the Impact of the Natural and Human Entity in Land Use in District of Albotana, Sudan. (In Arabic)

[7] Mohamed, G.E. (2008) Socioeconomic Aspects of Natural Vegetation Cover Affecting Rural Communities Sustainable Livelihood. Case Study, North White Nile State, Sudan.

[8] Foley, J.A., DeFries, R., Asner, G.P., Barford, C., Bonan, G., Carpenter, S.R., Chapin, F.S., Coe, M.T., Daily, G.C. and Gibbs, H.K. (2005) Global Consequences of Land Use. Science, 309, 570-574. http://dx.doi.org/10.1126/science.1111772

[9] Penner, J.E. (1994) Atmospheric Chemistry and Air Quality. Changes in Land Use and Land Cover: A Global Perspective, 175-209.

[10] Sala, O.E., Chapin III, F.S., Armesto, J.J., Berlow, E., Bloomfield, J., Dirzo, R., Huber-Sanwald, E., Huenneke, L.F., Jackson, R.B. and Kinzig, A. (2000) Global Biodiversity Scenarios for the Year 2100. Science, 287, 1770-1774. http://dx.doi.org/10.1126/science.287.5459.1770

[11] Tolba, M.K. (1984) A Harvest of Dust? Environmental Conservation, 11, 1-2. http://dx.doi.org/10.1017/S0376892900013424

[12] Stimson, H.C., Breshears, D.D., Ustin, S.L. and Kefauver, S.C. (2005) Spectral Sensing of Foliar Water Conditions in Two Co-Occurring Conifer Species: Pinus edulis and Juniperus monosperma. Remote Sensing of Environment, 96, 
108-118. http://dx.doi.org/10.1016/j.rse.2004.12.007

[13] Bao, L. and Cui, Y. (2005) Prediction of the Phenotypic Effects of Non-Synonymous Single Nucleotide Polymorphisms Using Structural and Evolutionary Information. Bioinformatics, 21, 2185-2190. http://dx.doi.org/10.1093/bioinformatics/bti365

[14] Biggs, R., Simons, H., Bakkenes, M., Scholes, R.J., Eickhout, B., van Vuuren, D. and Alkemade, R. (2008) Scenarios of Biodiversity Loss in Southern Africa in the 21st Century. Global Environmental Change, 18, 296-309. http://dx.doi.org/10.1016/j.gloenvcha.2008.02.001

[15] Metzger, M.J., Rounsevell, M.D.A., Acosta-Michlik, L., Leemans, R. and Schröter, D. (2006) The Vulnerability of Ecosystem Services to Land Use Change. Agriculture, Ecosystems \& Environment, 114, 69-85. http://dx.doi.org/10.1016/j.agee.2005.11.025

[16] FAO (2001) Global Forest Resources Assessment 2000. Main Report. FAO Forestry Paper No.140, Rome.

[17] Kerr, J.T., Kharouba, H.M. and Currie, D.J. (2007) The Macroecological Contribution to Global Change Solutions. Science, 316, 1581-1584. http://dx.doi.org/10.1126/science.1133267

[18] Matson, P.A., Parton, W.J., Power, A. and Swift, M. (1997) Agricultural Intensification and Ecosystem Properties. Science, 277, 504-509. http://dx.doi.org/10.1126/science.277.5325.504

[19] Turner, B.L., Skole, B., Sanderson, S., Fischer, G., Fresco, L. and Leemans, R. (1995) Land-Use and Land-Cover Change: Science Research Plan. IGBP Report, 35. IGBP, Stockholm, 132.

[20] Eltayeb, G.E. (2001) Eltayeb, G.E. (2001) Human Development Paper. The Civil Society Preparatory Conference for the (Rio+10) Summit Conference on Sustainable Development, 2-4 October 2001, Khartoum, 20.

[21] Mohamed, A.A., Sharifi, M.A. and van Keulen, H. (2000) An Integrated Agro-Economic and Agro-Ecological Methodology for Land Use Planning and Policy Analysis. International Journal of Applied Earth Observation and Geoinformation, 2, 87-103. http://dx.doi.org/10.1016/S0303-2434(00)85003-5

[22] HCENR (2000) The Sudan's National Biodiversity Strategy and Action Plan. Higher Council of Environment and Natural Resources (HCNR), Ministry of Environment and Tourism and IUCN with Support from UNDP, Khartoum. 75.

[23] Eltayeb, G.E. (2003) Khartoum, Sudan. Un-Habitat Case Studies, UK. London, 1-20.

[24] Abu-Saleem, M. (1991) The History of Khartoum, Dar Al-Jeel, Beirut. (In Arabic)

[25] Ali, S.A. (1999) Greater Khartoum: The Horizontal Expansion and Its Impact on the Development of Settlement. Unpublished MA Dissertation, Department of Geography, University of Khartoum, Khartoum. (In Arabic)

[26] Collins, R.O. (1990) The Waters of the Nile: Hydropolitics and the Jonglei Canal 1900-1988. Clarendon Press, Oxford. 